\title{
Creative undisciplining: Report on the 6th International Conference on Community Psychology, Durban, South Africa, 27-30 May 2016
}

\author{
$[B R I E F \mid N G]$
}

\author{
You may write me down in history \\ With your bitter, twisted lies, \\ You may trod me in the very dirt \\ But still, like dust, I'll rise. \\ - Maya Angelou, Still I rise
}

So don't you forget (no way) your youth, Who you are and where you stand in struggle

- Bob Marley, So much things to say

\author{
Nick Malherbe, \\ Rebecca Helman, \\ \& Josephine Cornell \\ Institute for Social and \\ Health Sciences, University \\ of South Africa, \\ \& South African Medical \\ Research Council-University \\ of South Africa Violence, \\ Injury and Peace \\ Research Unit,
}

Johannesburg \& Cape Town
An open letter to Bob Marley, which called for a re-animation of a decolonial, humanising psychic revolt - the echo of Thabo Mbeki's iconic I am an African speech - a screening of Maya Angelou's rendition of her rousing poem, Still I Rise; a night of song and dance; a visual display of protest against the Brazilian coup d'état; and unrestrained emotion in response to stirring human rights documentary films were just a few of the events that made the $6^{\text {th }}$ International Conference on Community Psychology (ICCP2016) a site of "creative undisciplining". This term, which Professor Nelson Maldonado-Torres used in his keynote address to refer to the student protests that have been occurring around the world in response to colonial, and neoliberal inequalities, appears an apt description for this conference, which 
opened up a space for critical interrogation of the discipline of community psychology in varied and creative ways.

The conference, held at the Durban International Convention Centre, South Africa on 27-30 May 2016, was hosted by the University of South Africa (UNISA), the South African Medical Research Council (SAMRC), and the Psychological Society of South Africa (PsySSA), and co-chaired by Professor Mohamed Seedat from UNISA and Dr Shahnaaz Suffla of the SAMRC. This is the first time that this conference has been held on the African continent. The conference theme, Global dialogues on critical knowledges, liberation and community, facilitated a space in which to critique the dominant knowledge systems in community psychology, which are considered to be largely underpinned by imperialist, Eurocentric epistemologies and frameworks. The theme called for the conscious decolonisation of knowledge creation, methodologies and processes that are perpetuated within colonial discourses.

Four hundred and sixty-three delegates representing 46 countries participated in keynote addresses, numerous oral, innovative and poster presentations, as well as roundtable discussions and symposia. Added to this, three documentaries were screened in an attempt to further stimulate conversations that are typically positioned outside of that which is understood as community psychology and, in the process, to interrogate accepted notions of what constitutes community psychology. Each presentation was situated within one of the conference's four thematic tracks: Knowledge production and contestation in Community Psychology; Decoloniality, power and epistemic justice; Community Psychology in context; and Teaching and learning in Community Psychology. These four tracks echo the multifaceted psychosocial, economic and geo-political discourses that have been raised by scholars, practitioners, students and activists around the world in relation to the everyday violences, multitude of injustices, and other social oppressions that have come to define the lived realities of the world's majority.

The three keynote addresses were delivered by Professor Nelson Maldonado-Torres from Rutgers University, USA; Dr Shose Kessi from the University of Cape Town (UCT), South Africa; and Professor Ibrahim Makkawi from Birzeit University, Palestine, and were all underpinned by a focus on decoloniality. The first keynote address, by Maldonado-Torres, What is a decolonized community?: A Fanonian meditation, was an engaging account of the incomplete project of decolonisation and the possibility of forming decolonised communities. Of particular interest was his description of decoloniality as "creative undisciplining". On the second day of the conference, Kessi's stimulating address, entitled Community social psychologies for decolonization: An African perspective on epistemic justice in Higher Education, reflected on the possibilities

PINS [Psychology in Society] 51 • $2016 \mid 96$ 
and limitations of community social psychologies in carving out a decolonising framework for the university in Africa. In particular, Kessi highlighted the work of the Black Academic Caucus at UCT and its vision of a decolonised university. In the final keynote address of the conference, The challenges of teaching and programming for decolonizing Community Psychology: Reflections from a prolonged colonial context, Makkawi shared a thought-provoking account of the commonalities and variations in the experiences of community psychologists in Latin America, South Africa and Palestine who have attempted to decolonise community psychology despite limited support from their institutions.

While the conference was marked by a wide variety of engaging, critical and innovative engagements, three key events bear mentioning. Firstly, the invited symposium Applying community psychologies to African realities or centring African psychologies in working with local communities, chaired by Professor Kopano Ratele from the University of South Africa, provided a platform for leading South African academics to engage with how their own empirical and theoretical work contributes to the development of African-centred interventions with and for African communities, as well as reflect on their own quests for a liberatory model that addresses various facets of imperialist knowledge systems. This symposium highlighted, as Ratele remarked, that "decolonisation is a seriously violent act that must go beyond just tinkering with the system".

Secondly, the screening of the documentary Four days in May by liberation psychologist, Professor Deanne Bell, was an example of the how innovative methods and dialogues are central to the processes of decolonisation, liberation and critical knowledge production. This film documents the 2010 police and army occupation of Tivoli Garden, an inner city community in Kingston, Jamaica from the perspective of those who were victimised in the atrocity. The project demonstrated how arts-based research can disrupt oppressive actions taken against those who have been marginalised by the state, through the creation of a space for a socio-political inclusion that is able to contribute to societal reformulation. The screening of the documentary was followed by critical and emotional reflections on issues of voice, representation and working with trauma.

Thirdly, in a true moment of creative disruption, on the second day of the conference a group of delegates established an additional conference track, dubbed Track $X$. This track encouraged attendees to reflect on, engage with, and contribute to the conference dialogue through an innovative communication platform. Delegates wrote down their messages and thoughts about the conference. These were then exhibited across the conference venue. Track $X$ represented a unique enactment of delegates' constructions of the conference experience. 
The conference highlighted a number of important challenges facing the discipline of community psychology, particularly in relation to issues of decolonisation, liberation and the production of critical knowledges. A call to disrupt imperialist, colonial, neo-colonial, ethnocentric, racist and sexist discourses which permeate both the academic and community contexts in which we work was reiterated throughout the various presentations and engagements. The conference centred the need to critique, dismantle and disrupt the community-engaged work of others, as well as that of ourselves.

With respect to disruption, many presentations - as well as the subsequent engagement with these presentations - emphasised the importance of a continuous reflexivity among researchers. Although being immersed in the academy may imbue researchers within an inherent knowledge system that is both formed and informed by colonial knowledge constructs, it is essential that researchers engage with their particular positionalities, and critically reflect on each aspect of the research process. The conference allowed a space in which delegates were able to undertake some of the difficult liberatory work that meaningful reflexivity requires. It was stressed, particularly in the conference's keynote addresses, that essential to the decolonising project is the manner in which community psychologists enact and engage with their work.

In the closing ceremony, the conference chairs shared a statement calling on all concerned global citizens to support and pledge solidarity to the academics of Turkey and Palestine, and the people of Brazil. Amongst other injustices, this statement noted the wrongful criminalisation of Turkish academics; the daily military violence and repression faced by Palestinian academics, students and the community at large in Occupied Palestinian Territories; and the coup currently underway in Brazil. Those wishing to sign the statement and add their voices of support can find it here:

http://bit.ly/1UpiqmS

The conference concluded with a handover to the hosts of the next International Conference on Community Psychology, which will be held in Santiago, Chile in 2018. 